\title{
CONTACT METAMORPHISM OF A BASIC IGNEOUS ROCK
}

BY ULYSSES SHERMAN GRANT

(Presented before the Society December 30, 1899)

\section{CONTENTS}

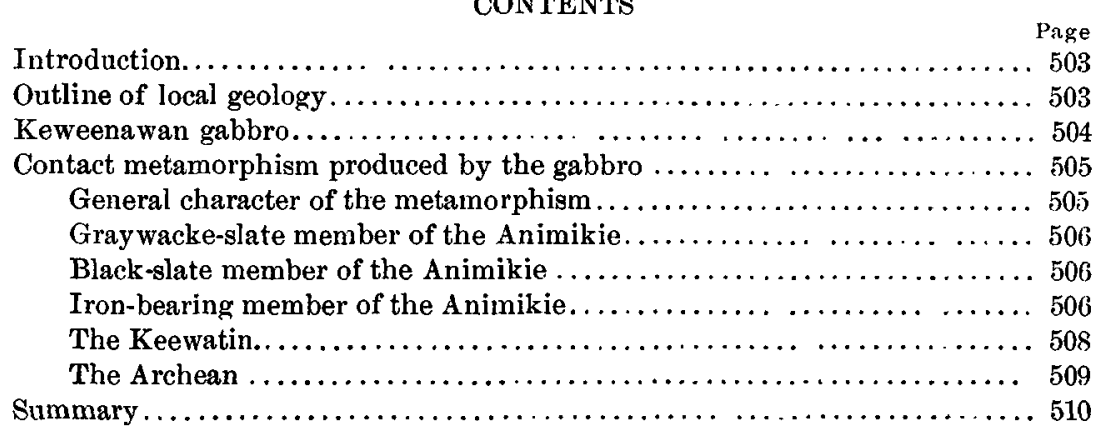

\section{INTRODUCTION}

In volumes 4 and 5 of the Final Report of the Geological and Natural History Survey of Minnesota, and in some of the annual reports of the same survey, mention is frequently made of certain peculiar crystalline rocks which occur along the northern edge of the great gabbro mass of northeastern Minnesota. The rocks in question furnish one of the most interesting cases of metamorphism of a series of rocks of varied lithology by the contact effect of a basic igneous mass. It is the object of this paper to present in outline an account of the phenomena here seen.

\section{OUtuine of LOCAL Geology}

The triangular area of Minnesota lying north of lake Superior is underlain by rocks of pre-Cambrian age. In general these are disposed in belts, which trend east-northeast and west-southwest. Those of greatest age are toward the north, so that in traversing this district from the Canadian boundary south to lake Superior one passes over rocks of the 
following ages in the order named: Archean, Lower Huronian (or Keewatin), Upper Huronian (or Animikie), and Keweenawan. These series are separated by unconformities. The first two series frequently have been closely folded, while the last two dip toward the south-southeast at angles of from 5 to 20 degrees.

The Archean consists in the main of greenstones and of granites, more or less schistose. The former were originally basic igneous rocks, and in most cases they have not as yet been carefully separated from the overlying Keewatin, which also contains masses of greenstone. Granites, intrusive into the Keewatin, also occur.

The Lower Huronian (or Keewatin) is composed of a variety of sedimentary and igneous rocks, the most numerous of which are conglomerates, graywackes, jaspilytes, greenstones, and slates and schists of several kinds.

The Upper Huronian (or Animikie) rests unconformably upon the older rocks, and along the contact with the gabbro has not been subjected to the intense dynamic action which has folded and sheared these older rocks. The dip of the A nimikie averages about 10 degrees toward the south or south-southeast, but where it disappears under the gabbro the dip is commonly much steeper. The Animikie is separable into four members, in ascending order, as follows:

1. The quartzite member.

2. The iron-bearing member, in which the important iron deposits of the Mesabi range occur.

3. The black-slate member, which is composed essentially of black, carbonaceous, frequently very fissile, slates.

4. The graywacke-slate member, consisting of black to gray slates and fine grained graywackes, with some flinty slates and slaty quartzites.

The lower member is lacking in the district where the gabbro occurs.

The Keweenawan consists at its base of a mass of gabbro, which is frequently associated with more acid rocks of somewhat later date. Above these is a series of basic igneous rocks, with the uppermost parts of which some sandstones and conglomerates are intercalated.

\section{Keweenawan Gabbro}

The gabbro occupies a roughly crescentic area which reaches lake Superior at its western end, but elsewhere is several miles north of this body of water. The crescent is some 125 miles in length, and the total surface area underlain by the gabbro is approximately 1,000 square miles. It is therefore a mass of considerable size.

The gabbro is a coarse grained aggregate of plagioclase, which is near 
labradorite; augite, which is often diallagic; olivine, and magnetite, with occasionally hypersthene, biotite. hornblende, and minor accessory minerals. In general, the mass is of fairly uniform composition. Variations, however, take place mainly in three directions : First, by increase of feldspar the rock becomes an anorthosite; second, by increase of feldspar and olivine a forellenstein is formed ; third, by increase of magnetite masses of titaniferous magnetic iron ore originate. Along its northern limit the gabbro, while at times assuming a finer grain, usually preserves its distinctly coarse grain and granular texture to its contact with the underlying rocks.*

Although this large mass of rock has been regarded as the earliest flow or series of flows of Keweenawan time, there has been a recent trend of opinion toward the conclusion that the gabbro is not of extrusive, but more probably of intrusive nature, and that it has the form of a laccolite. There is, so far as known, no separation of this enormous mass into distinct beds or flows similar to the other flows of Keweenawan age, nor have any of the characteristic textures of surface rocks been reported from the gabbro proper. It must be said, however, that the southern or upper side of this mass has not been studied in detail. Moreover, the marked metamorphosing effects which the gabbro has had on the underlying rocks along its northern border-effects described below-also point to the non-extrusive character of the mass.

\section{Con'fact Metamorphism produced by the Gabbro}

GENERAL CHARACTER OF THE METAMORPHISM

This metamorphism is very noticeable, and consists of a partial or a complete recrystallization of the adjacent rocks. Complete recrystallization is the rule near the contact, and in places this extends 500 feet from the contact. A partial recrystallization is at times noticeable for a distance of a quarter of a mile or more from the present surface limits of the gabbro.

In northwestern Cook county, Minnesota, the gabbro is in contact with the uppermost or graywacke-slate member of the Animikie. In going westward this igneous mass cuts across the strike of the Animikie, touching the black-slate and the iron-bearing members, then strikes the Keewatin, and finally reaches the Archean. In the rocks of each of these series certain characteristic contact phenomena can be seen. In Lake county the gabbro, except for isolated patches of the iron-bearing member

\footnotetext{
*'The petrography of the gabbro has been described by W. S. Bayley (Journal of Geology, 1893, vol. 1, pp. 688-716), and by N. H. Winchell and the writer (Geological and Natural History Survey of Minnesota, Final Report, vol. 5 , in press).
} 
of the Animikie, is in contact with still older rocks, and in eastern Saint Iouis county the Animikie again emerges from beneath the gabbro.*

GRA YWACKE-SLATE MEMBER OF THE ANIMIKIE

Where the gabbro is in contact with the uppermost member of the Animikie there is a marked contact zone, in which. the sedimentary rocks are much hardened and have a massive aspect, appearing at a distance like igneous rock, while close to the gabbro they are completely recrystallized. Near the contact the more silicious strata have been turned into completely crystallized quartzites. The less pure silicious rocks consist of granitic aggregates of quartz, feldspar, biotite, and muscovite in varying proportions, with occasionally cordierite. It is to be noted that the minerals common to the gabbro, especially pyroxene and olivine, which are so abundant in the metamorphosed rocks of the ironbearing member of the Animikie and of the Archean, described below, are absent from these silicious rocks at the gabbro contact. A short distance from the contact the recrystallization becomes less complete, although biotite and muscovite have been developed.

\section{BLACK-SLATE MEMBER OF THE ANIMIKIE}

The known exposures do not show any contacts of the gabbro on the next lower or black-slate member of the Animikie, but in a few places somewhat removed from the contact and in the immediate vicinity of sills of diabase cordierite has been developed in these slates. A fragment referred to these black carbonaceous slates and included in the gabbro is now a completely crystallized aggregate of quartz, graphite, and biotite, with large plates of beautifully pleochroic hypersthene, which incloses the other minerals in a poikilitic manner.

IRON-BEARING MEMBER OF THE ANIMIKIE

It is in the next lower or iron-bearing member of the Animikie that the most interesting contact phenomena are exhibited. This member is the one in which, farther west, the immense hematite deposits of the Mesabi range occur. 'The original rock is regarded as a glauconitic greensand, in which there is more or less iron carbonate. This rock has been altered to a quartz-magnetite-amphibole slate, the amphibole being in the form of actinolite, grünerite, cummingtonite, and hornblende. This quartz-magnetite-amphibole slate, commonly known in the Lake Superior region as actinolite schist, has been profoundly changed by the gabbro, and the resulting rock is a coarse grained aggregate of quartz, magnetite, olivine (which is frequently fayalite), hypersthene, augite-

* Cf. Geol. and Nat. Hist. Survey of Minn., Final Rept., 1890, vol, 4, pls. 67, 68, 69. 
hornblende, and occasionally grünerite, and cummingtonite. These rocks, like the rocks from which they are derived, are beautifully banded, the separate bands being composed of quartz, or of magnetite, or of silicates, or of a mixture of any two or more of the minerals. The texture of the different bands is granitoid as a rule, but in some cases one mineral, notably the hypersthene, is developed into large plates, which include the other minerals in a poikilitic manner. These contact rocks, which on account of the abundance of magnetite and olivine are sometimes called the olivinitic iron ores, are so peculiar that attention has been called to them by several geologists. As they have been referred either to the Lower Huronian or to the Upper Huronian (or Animikie) or to the gabbro (Keweenawan) itself by different geologists, it seems best to present briefly the evidence proving their real age.* This seems best also because, on account of the abnormal mineral composition of these rocks, there may be some hesitancy about accepting their original sedimentary nature.

The facts which show the Animikie age of the rocks in question may be stated as follows:

1. The outcrops, while not absolutely continuous, are of sufficient frequency to allow the gradual tracing of the quartz-magnetite-amphibole slates along their strike into these highly crystalline rocks.

2. In following these outcrops a gradation in crystalline and mineral nature can be traced from the slates to the rocks in question.

3. Certain structural features of the region, the details of which can not be given here, are most readily explained by assuming the Animikie age of the olivinitic iron ores.

4. The rocks underlying and those overlying the olivinitic iron ores are the same as those underlying and overlying the less altered slatesthat is, the stratigraphic positions of the two are similar.

5. The rapid alternations of bands of different compositions in the two rocks are exactly similar.

6 . The anomalous mineral composition of these highly crystalline rocks can be explained as the direct result of the mineral composition of the Animikie rocks from which they were derived. The peculiar mineral character consists in the presence of so many and such large amounts of minerals which are not commonly found in metamorphosed sediments, but which are characteristic of basic igneous rocks-that is,

* Of the geologists who have studied the rocks in question the writer understands that J. M. Clements, A. H. Elftman, C. K. Leith, C. R. Van Hise, and H. V. Winchell agree with the interpretation here given, namely, that these rocks are parts of the iron-bearing member of the Animikie metamorphosed by the gabbro. N. H. Winchell, while formerly holding this interpretation, now regards these rocks as of Keewatin age. W. S. Bayley has deseribed them, or at least large parts of them, as peripheral phases of the gabbro. 
olivine, augite, and hypersthene. To present this point more definitely, it can be stated, first, that from the quartz and magnetite of the slates can be formed the quartz and magnetite of the metamorphic rocks; second, that from the actinolite and hornblende of the slates can be formed the augite and the hornblende of the metamorphic rocks; third, that from the grünerite $\left(\mathrm{FeSiO}_{3}\right)$ can be formed the fayalite $\left(\mathrm{Fe}_{2} \mathrm{SiO}_{4}\right)$; fourth, that from the cummingtonite $\left([\mathrm{MgFe}] \mathrm{SiO}_{3}\right)$ can be formed the olivine $\left([\mathrm{MgFe}]_{2} \mathrm{SiO}_{4}\right)$ and the hypersthene $\left([\mathrm{FeMg}] \mathrm{SiO}_{3}\right)$. It is thus clear that the materials necessary for the formation of the minerals of the metamorphic rocks were all present in the original quartz-magnetiteamphibole slates. It is not the intention of the writer to state that there was no transfer of material from the gabbro during this metamorphism. This may have taken place, but it is not necessary to assume even a limited transfer, for the materials requisite for the manufacture of the minerals of the metamorphosed rocks already existed in the iron-bearing slates.

Turning now to the reasons for regarding these peculiar metamorphic rocks as not facies of the gabbro, it may be stated:

1. That the rocks in question contain no feldspar, which is the most abundant mineral in the gabbro.

2. That quartz is abundant in the metamorphic rocks, while it is absent in the normal gabbro. If these rocks were facies of the gabbro we would have the anomalous feature of much free quartz in an ultra-basic rock.

3. That the magnetite of the olivinitic iron ores is not titaniferous, while the magnetite masses of the gabbro are highly titaniferous, and the magnetite of the ordinary gabbro is also titaniferous.

4. That where the two rocks come into contact there is no gradation between them, but a sharp and definite separation can be made. Moreover, at the contact the gabbro is finer grained than aw ay from this line. The same sharp separation can be made where sills from the gabbro lie in the iron-bearing rocks, and here the fineness of grain of the sills at the contact is very marked.

5. That there are nowhere in the gabbro such intimate laminations and bandings as in the rocks in question.

These iron-bearing rocks have suffered much more extensive recrystallization than other strata with which the gabbro has come in contact. The exact reason for this is not clear, but probably the peculiar composition of these rocks in part conditioned the result.

\section{THE KEEWATIN}

Where the gabbro is in contact with strata of Lower Huronian age there has been the usual recrystallization, but as these strata are diverse 
in mineral composition the resulting metamorphic rocks vary greatly. A very prominent feature of these altered rocks is the presence of much biotite, while in the intermediate vicinity of the contact hypersthene is developed frequently in poikilitic plates.

THE ARCHEAN

Along the northern border of the gabbro the Archean is represented by two types of rocks, granites and greenstones. Contact metamorphism in the first of these has not been noted; in fact, it may be questioned whether the gabbro induced any marked changes in these acid rocks; but in the other type, the greenstones, a series of changes has taken place which has produced rocks of a peculiar nature. Originally the greenstones here considered consisted of gabbros, diabases, diorites, or the finer grained extrusive and fragmental equivalents of these rocks. They have been subjected to many vicissitudes, and in their present composition they are aggregates of hornblende, plagioclase, kaolinite, epidote, quartz, and minor alteration products. The metamorphism induced by the gabbro has been of a nature which has tended to reproduce the original minerals of these greenstones. The result is in some cases quite similar to a fine grained gabbro. In fact, some of these metamorphosed greenstones have been described as parts of the great gabbro mass, while, on the other hand, certain fine grained and granulitic phases of the gabbro have been referred to these changed greenstones. The resemblance between the two rocks is quite marked on surfaces which have been exposed to the weather, both forming yellow granular masses, which crumble readily under the hammer. There is, however, a difference between these apparently similar rocks of diverse origin. and a judicial combination of field evidence and microscopical study will commonly enable one to decide to which category the rock of a given outcrop belongs. The granulitic gabbros are confined within (that is, to the south of) the northern boundary line of the gabbro mass. This line can be, and in fact for a considerable distance has been, carefully located. The metamorphosed greenstones are without (that is, to the north of) this boundary, and, moreover, they can usually be traced directly into the less altered greenstones, the zone in which the complete recrystallization has taken place being commonly a comparatively narrow one. In thin sections the granulitic gabbros present a typically granular texture and the grains are very uniform in size. Hornblende is not common, and olivine and hypersthene are at times found.

In the metamorphosed greenstones the texture is not so typically granular, and the grains vary considerably in size, although many of them have the approximately circular outlines which are so noticeable 
in the granulitic gabbros. Moreover, in the metamorphosed greenstones there is usually much hornblende and sometimes a little quartz, and it is only in close proximity to the gabbro that augite and hypersthene are found in any considerable amounts. Olivine has not been noted, and quite frequently the hornblende and hypersthene are in poikilitic plates.

\section{Summary}

In conclusion, it may be stated that the great mass of gabbro at the base of the Keweenawan in Minnesota has features which indicate its intrusive'rather than its extrusive nature; that one of the most important of these features is the marked contact zone along the lower or northern side of this mass; that in this zone a complete recrystallization of the strata has been effected, at times for a distance of a few hundred feet from the igneous rock, with less pronounced effects extending for a quarter of a mile or more; that the rocks resulting from the contact metamorphism of the iron-bearing member of the Animikie are peculiarly rich in minerals of the basic rocks-that is, in augite, hypersthene, and olivine; that the materials for these minerals were present in the quartz-magnetite-amphibole slates of the Animikie, and consequently that it is not necessary to consider these minerals as derived from the gabbro; and that the contact effects on some altered basic igneous rocks have been to reproduce the original mineral characters of these rocks and to produce textures partially similar to true igneous rocks. 